\title{
Ethyl Methane Sulfonate Effect on Total Lipids of Chlorella vulgaris isolated from Nile River Egypt
}

\author{
Mohamed A. Gomaa ${ }^{1}$, Mohamed H. Refaat ${ }^{1}$, Tamer M. Salim ${ }^{1}$, Abo El-Khair B. El-Sayed ${ }^{2}$ and Makhlof \\ M. Bekhit ${ }^{1}$ \\ ${ }^{1}$ Department of Genetics, Faculty of Agriculture, Benha University, Qalubia, Egypt \\ ${ }^{2}$ Algal Biotechnology Unit, National Research Centre, Dokki, Giza, Egypt
}

Corresponding author: mohamedagomaa06@gmail.com

\begin{abstract}
Chlorella vulgaris species was isolated from Nile River in Qalubia Governorates, Egypt. The highest constant of growth $(\mu=1.5)$, and the lower time of reproducing a generation $(\mathrm{G}=0.2)$. The green alga was identified using 18S rRNA gene amplification followed by sequencing the resultant sequence was compared with those available on the NCBI website database through the BLAST bioinformatics tool. The percentage of lipids synthesized was $20 \%$. In order to increase lipid contents in this green alga was made chemical mutation by EMS. Using three concentrations from EMS $(0.1,0.01$ and 0.001$)$ for two hours. The resulted in the treatment of concentration 0.1 decrease total lipid to $16.2 \%$ in by concentration 0.01 almost no change the total lipids were equal with wild strain. By the concentration 0.001 a significant increase in total lipids content as it reached $25 \%$ compared with wild strain.
\end{abstract}

Key words: Chlorella vulgaris, 18 S rRNA gene, EMS, and Total lipids.

\section{Introduction}

Chlorella vulgaris Beijerinck is mono-cell green algae. They are everywhere, from land to sea, from cold water to warm water, to rocks and sand. They have served as model organisms for the leading physiological and biochemical studies in the process of photosynthesis and reduction of nitrates (Huss et al., 1999). Moreover, collective cultures of Chlorella in agriculture has been used can a single cell for both humans and animals, in the field of biotechnology for waste recovery agents Treatment, and biofuel technology as microbial energy producers (Golueke and Oswald., 1964; Fogg., 1971; Abbott and Cheney., 1982). From the most famous microalgal species around the world, Chlorella vulgaris; after describing Chlorella vulgaris Beijerinck about 120 years ago, more than 100 species have been identified morphologically since species description (John et al., 2003). The microalgae simple identify extremely hard because of the size is small molecular techniques can be allowing an evaluation of the legitimacy of the morphological species idea for general microalgae and finally, these techniques permit for partitioning and distribution of the microorganisms. For a lot of types of microorganisms, the gene most generality appoint for studies of diversity is the small-subunit ribosomal RNA gene (16S rRNA in prokaryotes and 18S rRNA in eukaryotes) Fawley et al., 2004.

Furthermore, many Chlorophyceae groups find in the genus Chlorella was switched to Scenedesmus according to $18 \mathrm{~S}$ rRNA sequence analysis (Hanagata., 1998). Although, a lot of studies have observed that the $18 \mathrm{~S}$ rRNA is in many cases also conserved to differentiate between closely linked genera and species (Luo et al., 2010). Ethyl methane sulfonate (EMS) is a single functional absorption agent found to be mutagenic a wide range of genetic testing systems from viruses to mammals.

It has also been shown to be carcinogenic in mammals. Alkylation of nucleophilic, cellular sites are caused by EMS via a mixed interaction mechanism $\mathrm{SN}_{1} / \mathrm{SN}_{2}$. While, methylation of DNA occurs mainly in nitrogen sites in bases, Due to partial $\mathrm{SN}_{1}$ reaction character, EMS is also able to produce high levels of alkali in oxygen such as $O^{2}$ of guanine and phosphate DNA groups. Genetic data obtained using microorganisms indicate that EMS can produce both GC to AT and AT to GC transition mutations. There is also some evidence to suggest that EMS can cause introductions or deletions between rules as well as more extensive deletions within the group. In higher living organisms, there is clear evidence that EMS can break chromosomes, although the mechanisms involved are not well understood. A hypothesis often cited is that the DNA bases interpreted by the EMS system (often the $\mathrm{N}-7$ site of the guanine) gradually degrade from deoxyribose on the DNA backbone, leaving behind an unstable (or possibly an apyrimidinic) site that can cause to break a strand of DNA. There are also data indicating that some chromosome proteins in some sperm in mice may be an important factor in causing chromosomal fragments (Gary., 1984) and Ethyl methane sulfonate (EMS) was the first factor found unequivocally to increase the proportion of mutants. (Loveless., 1958).

The present works aimed to isolation and genetic identification of rich oil content fresh water algae and develop total lipids for microalga Chlorella vulgaris strain isolated from Nile River in Qalubia Governorate, 
Egypt, to achieve this goal induced chemical mutation in order to increase total lipids content.

\section{Materials and Methods}

\section{Source of the isolation}

Chlorella vulgaris strain was isolated from fresh water of Nile River in Qalubia Governorate, Egypt. Isolation and purification of the microalgae were done by sub culturing and grown in BG-11 medium (Stanier et al., 1971). Samples were isolated as the cultures were maintained at $25^{\circ} \mathrm{C}$ under illumination

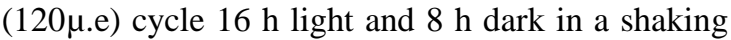
growth chamber at $90 \mathrm{rpm}$ and $\mathrm{pH}$ range (7.1).

\section{Growth studies:}

Growth was estimated according (Stein., 1973) by measuring the OD $650 \mathrm{~nm}$ for the culture by spectrophotometer:

Specific growth rate $(\mu)$, based on the equation $\mu=\ln \left(\mathrm{N}_{\mathrm{y}} / \mathrm{N}_{\mathrm{x}}\right) /\left(\mathrm{t}_{\mathrm{y}}-\mathrm{t}_{\mathrm{x}}\right)$, Where $\mathrm{N}_{\mathrm{y}}$ and $\mathrm{N}_{\mathrm{x}}$ are the numbers of cells $(\mathrm{N})$ at the start $\left(\mathrm{t}_{\mathrm{x}}\right)$ and the end $\left(\mathrm{t}_{\mathrm{y}}\right)$ of the logarithmic growth phase (Levasseur et al., 1993).

Generation time $(\mathrm{G})$ was determined using the following equation: $G=0.301 / \mu$ according to (Stein., 1973).

\section{Determination of total lipids:}

Lipids were determined according to the standard method A.O.A.C., (1984). A known weight was extracted with Petroleum ether $\left(60-80^{\circ} \mathrm{C}\right)$ for 24 hours in a Soxhlet apparatus, after which the solvent was evaporated, and the residue was dried to a constant weight at $95^{\circ} \mathrm{C}$.

\% Total lipid $=\underline{\text { Sample before determination-Sample }}$ after determination X 100

Sample before determination

\section{Extraction and purification DNA:}

Total DNA was extracted according to the method outlined by Doyle and Doyle (1987) Samples were suspended in the (CTAB) extraction buffer (3\% CTAB, 0.1 M Tris-HCl, 0.01 M EDTA, $1.4 \mathrm{M} \mathrm{NaCl}, 0.5 \% \beta$-mercaptoethanol, $1 \% \mathrm{PVP}$ ) at $\mathrm{pH}$ 8.0. The mixture was incubated at $60^{\circ} \mathrm{C}$ for one hour with shaking for every fifteen minutes and was cooled down to room temperature. DNA was then extracted with an equal volume of chloroform: isoamyl alcohol $(24: 1)$ and precipitated from the supernatant by the addition of one volume isopropanol. DNA extract was re-suspended in TE buffer. DNA quality was controlled by agarose gel electrophoresis.

\section{S rRNA Gene Identification:}

The genomic 18S ribosomal RNA gene region of microalgae was amplified by colony PCR as described previously by (Uclés., 2008) using the (Forward) $\mathrm{C}_{2}: 5^{\prime}>$ ATTGGAGGGCAAGTCTGGT $<3$ 'and (Reveres) $\mathrm{D}_{2}: 5^{\prime}>$ ACTAAGAACGGCCATGCAC $<3^{\prime}$ primers.

The PCR reaction were performed for the 18SrRNA gene in $25 \mu \mathrm{l}$ volume by mixing $30 \mathrm{ng}$ genomic DNA with $2 \mu \mathrm{l}$ of primer (10 p mole/ $\mu \mathrm{l})$ and master max (Takara, Japan) and PCR water. The PCR reaction continued with denaturation for $30 \mathrm{sec}$. at 95 ${ }^{\circ} \mathrm{C}$, followed by 30 cycles of $30 \mathrm{sec}$. denaturation at $95^{\circ} \mathrm{C}, 1 \mathrm{~min}$. annealing temperatures at $60^{\circ} \mathrm{C}$, and 1.0 min. extension at $72^{\circ} \mathrm{C}$. The 30 thermal cycles were followed by a final extension of $5 \mathrm{~min}$. at $72^{\circ} \mathrm{C}$. Following amplification, PCR products were electrophoresed on a $0.9 \%$ agarose gel and purified using a Thermo Scientific Gene Jet PCR purification Kit.

\section{S rRNA Gene Sequence analysis:}

The current 18S rRNA gene sequences were registered at DNA database under accession number, sequences were compared with those available in the GenBank database using Blast. Phylogenetic tree was constructed through two Bioinformatics Processes. In the first process, the nucleotide sequences of the recovered 18S rRNA gene phenotypes and their homologues sequences, from the DNA database, were aligned using the online program "Clustal Omega". In the second process, the aligned sequences were submitted to the MEGA7 software (http://www.megasoftware.net/) for drawing the phylogenetic tree. Phylogenetic tree was constructed by applying the algorithms maximum likelihood in MEGA software and used BioEdit version 7.2.5 in bioinformatics tools.

\section{Random Chemical mutation by (EMS) Ethyl Methane Sulfonate:}

Chlorella vulgaris isolates was grown to early exponential phase. Cell suspensions at $10^{7}$ cells $/ \mathrm{ml}$ were subjected to random mutagenesis by various concentrations of EMS (Sigma-Aldrich, USA) According to (Bongsoo et al., 2014):

- Samples of each algal culture (20ml each).

- Three concentrations of EMS each concentration its size final $1 \mathrm{ml}$ :

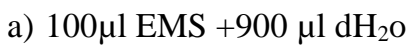

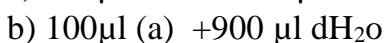

c) $100 \mu \mathrm{l}(\mathrm{b})+900 \mu \mathrm{ld} \mathrm{d}_{2} \mathrm{O}$

-Each of concentration three Treatment on Liquid culture $20 \mathrm{ml}$ culture $/ 100 \mu \mathrm{l}$ EMS(a, b and c).

-Put each Treatment in time 30min, 1hour and 2 hour. - Stop treatment: Preparation of a sterile solution of 5\% sodium Sayo sulfate put $1 \mathrm{ml}$ at the appropriate time to stop. 


\section{Results and Discussion}

\section{Algal Isolation for this study}

Green alga species was isolated from Nile River in Qalubia Governorate, Egypt. That isolate was characterized by $20 \%$ of total lipids. Oil determination was performed at the stationary growth phase. This green alga was tentatively identified as Chlorella vulgaris belonging to Chlorophyta (Fig.1). The Chlorella vulgaris isolate is optioned for this study morphologically circular small cell and the color is green.

\section{$18 S$ rRNA gene Sequences and phylogenetic tree}

$18 \mathrm{~S}$ rRNA gene sequences of the isolate the base size was $744 \mathrm{bp}$. The DNA sequences of this isolate showed $100 \%$ identity to Chlorella vulgaris. Although, morphological examination by light microscopy revealed that the strain had consistent morphology to Chlorella vulgaris. The result obtained was compared in the GenBank (NBCI).

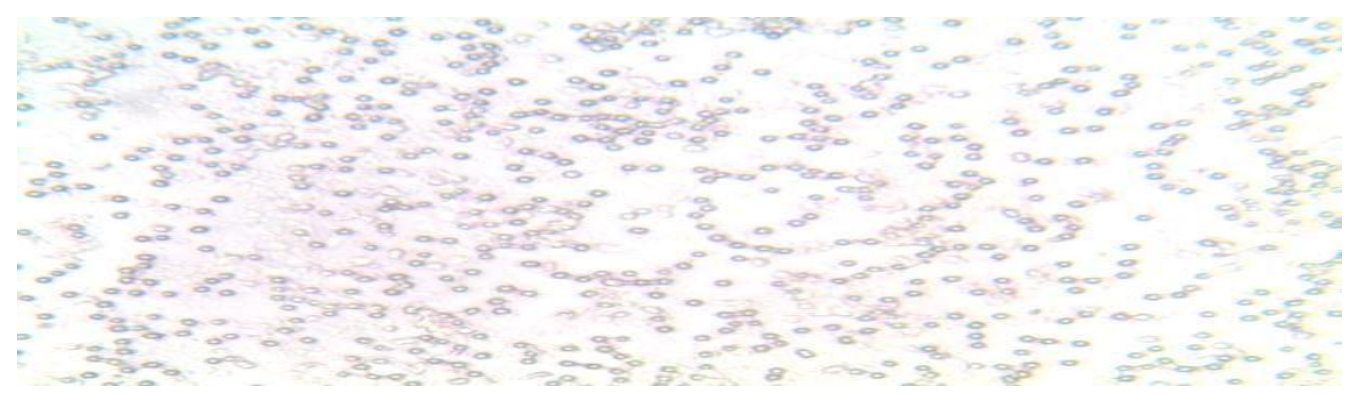

Fig.1. Microscopic Image for the isolate optioned for this study

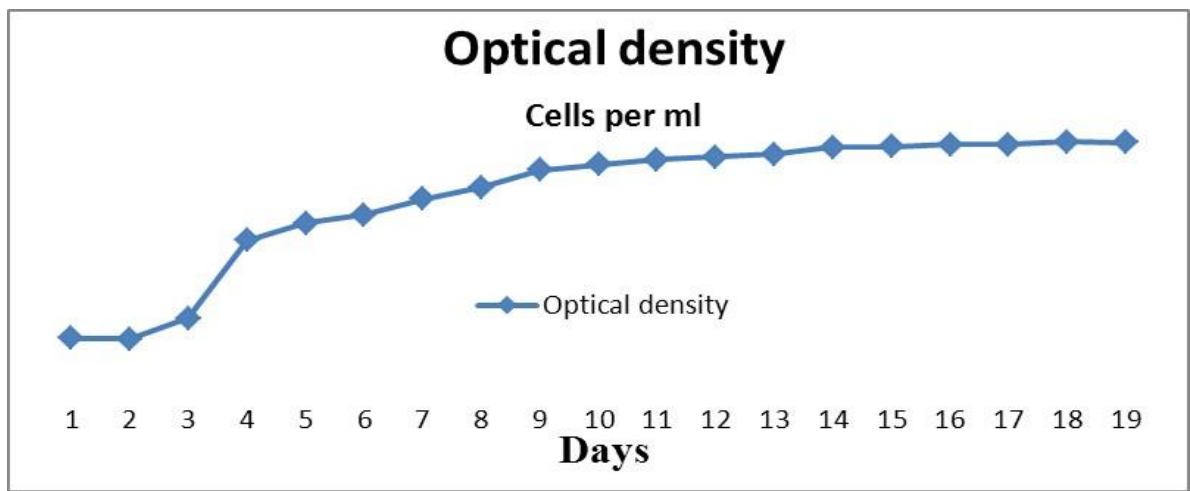

Fig.2. Growth curve for the isolate optioned for this study

\section{Growth study:}

Beginning logarithmic growth phase after the third day to the eleventh day then outset stationary growth phase to the eighteenth day then in the nineteenth day start death growth phase. The highest constant of growth $(\mu=1.5)$, and the lower time of reproducing a generation $(\mathrm{G}=0.2)$. Growth phase is important for now the appropriate time for the experiment. Content of lipids and the composition of fatty acids are also susceptible to changes during the growth cycle. In many algae species examined, observed increase in Triacylglyceride (TAGs) during the stationary growth phase (Bigogno et al., 2002 and Mansour et al., 2003). Fig. 2
The Sequences of Accession Number: LC333291 and ten Accession Numbers from GenBank was aligned using the online program "Clustal Omega" and phylogeny tree was submitted to the MEGA 7 software Analyses of Phylogenetic for the 18S rRNA sequences observed the relationship between the new Sequences of Accession Number:LC333291 and ten Accession Numbers from National Center for Biotechnology Information (NCBI) database, USA (http://www.ncbi.nlm.nih.gov).

The result showed that the present specimens were grouped in Phylum Chlorophyta (Fig. 3). The phylogenetic tree deducted from the sequence comparison of 18S rRNA region showed that the length of the branch that represents an amount genetic change of 0.0050 , and the $18 \mathrm{~S}$ rRNA-based phylogeny tree included five clades. The clades grouping had low support (bootstrap value between 7-87\%) and showed 
Table1.Percentage divergence between wild simple and10 Accession Number from the GenBank list

\begin{tabular}{|c|c|c|c|}
\hline Accession number & $\begin{array}{l}\text { Percentage divergence } \\
(/ 100)\end{array}$ & Rate of transition & $\begin{array}{c}\text { Rate of } \\
\text { trans version }\end{array}$ \\
\hline $\begin{array}{c}\text { Wild simple } \\
\text { (ID:LC333291) }\end{array}$ & -- & -- & -- \\
\hline ID:KX094755 & 0.0013 & 0.0013 & 0.0000 \\
\hline ID:JX097060 & 0.0013 & 0.0000 & 0.0013 \\
\hline ID:KU720636 & 0.0027 & 0.0013 & 0.0013 \\
\hline ID:KX094753 & 0.4355 & 0.0995 & 0.3360 \\
\hline ID:KT250599 & 0.0699 & 0.0188 & 0.0511 \\
\hline ID:X73992 & 0.0067 & 0.0027 & 0.0040 \\
\hline ID:AB006046 & 0.0242 & 0.0040 & 0.0202 \\
\hline ID:X63505 & 0.5992 & 0.1296 & 0.4696 \\
\hline ID:X56105 & 0.0094 & 0.0040 & 0.0054 \\
\hline ID:LC037427 & 0.0054 & 0.0027 & 0.0027 \\
\hline
\end{tabular}

*Neighbor-joining Method (Saitou and Nei., 1987)

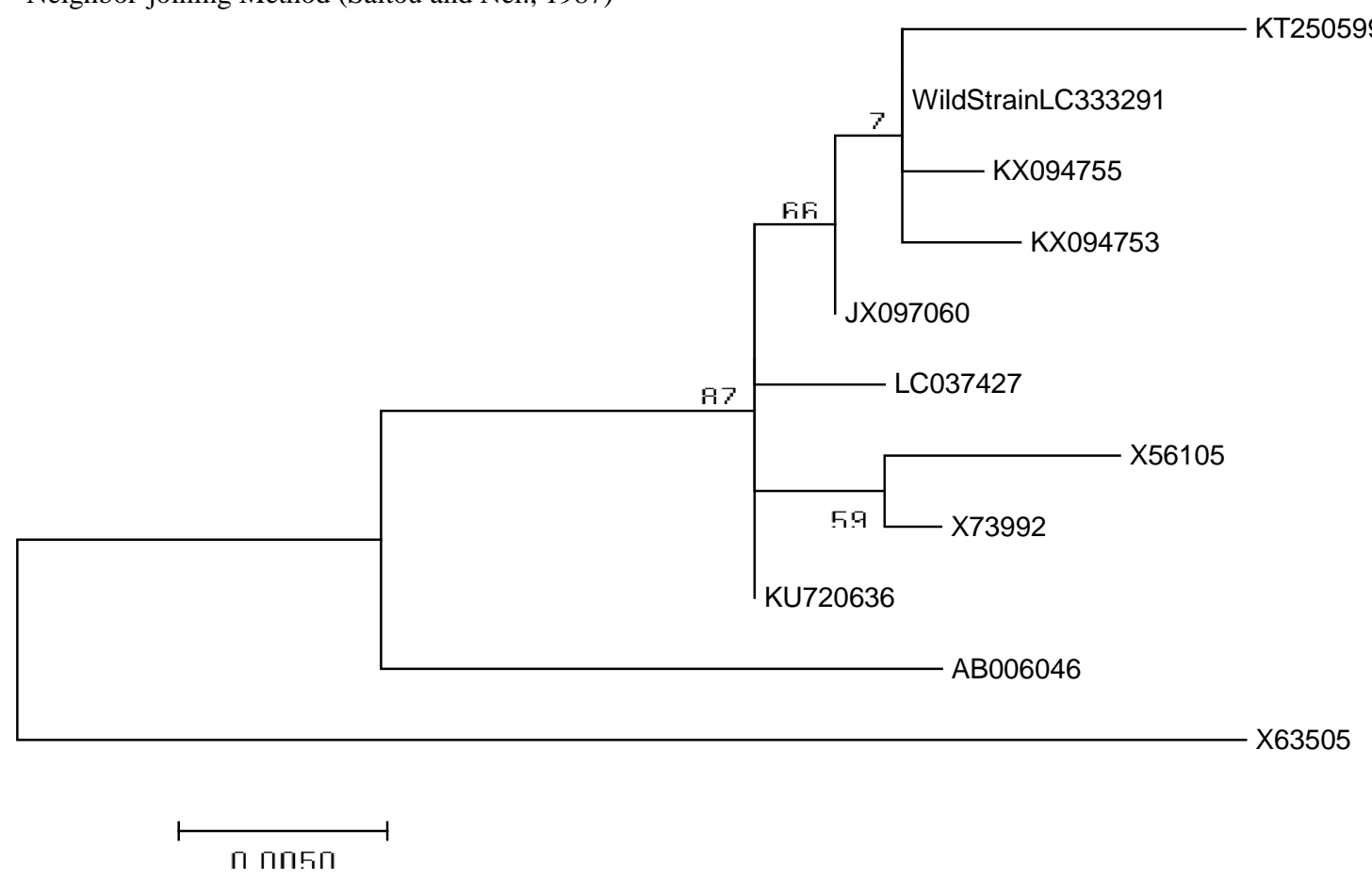

Fig.3. The Relationship between the sequences of Accession Number: LC333291 and 10 Accession numbers from gene bank. The Phylogenetic tree was constructed by applying the algorithms Neighborjoining Method.

that in (Table 1) the present specimen was placed in Chlorella vulgaris Sequence ID: LC333291 neighbor to Chlorella vulgaris Sequence ID: KX094755, Chlorella sp Sequence ID: - JX097060 and Chlorella vulgaris Sequence ID: KU720636.and Chlorella vulgaris Sequence ID: KX094753 and distant on Chlorella vulgaris Sequence ID: KT250599, Chlorella sp Sequence ID: X73992,Chlorella minutissima Sequence ID: AB006046, Chlorella saccharophila Sequence ID: X63505, Chlorella kessleri Sequence ID: X56105 and Chlorella sp Sequence ID: LC037427.
That is mean that is sequences common in Phylum Chlorophyta in the world in the different environment and under different conditions.

In this Phylogenetic found that: Average percent standard deviation $=2.59436$, Ln Likelihood = 3284.83696. In addition, estimated Empirical Base Frequencies: $A=0.24065, C=0.20617, G=0.29601$ and $\mathrm{T}=0.25717$ ).

I found Conserved regions Region (1): Position (1 to 66)

${ }^{1}$ ATTGGAGGGCAAGTCTGGTGCCAGCAGC CGCGGTAATTCCAGCTCCAATAGCGTATA TTTAAGTTG $^{66}$ and Region (2): Position (68 to 99) 
68TGCAGTTAAAAAGCTCGTAGTTGGATTT

$\overline{\text { CGGG }}^{99}$ and other regions contain little difference in DNA sequences.

Effect of Chemical mutation by EMS Ethyl Methane Sulfonate :

Genetic data obtained using microorganisms indicate that EMS can produce both GC to AT and AT to GC transition mutations (Gary., 1984).

In case of exposure to chemical mutation using EMS as an effort for total lipids improving. Using three concentrations from $\operatorname{EMS}_{1}(0.1), \operatorname{EMS}_{2}(0.01)$ and $\operatorname{EMS}_{3}(0.001)$ for two hours. The resulted in the treatment of concentration $\mathrm{EMS}_{1}$ decrease total lipid to $16.2 \%$ in by concentration $\mathrm{EMS}_{2}$ almost no change in the total lipids was equal with wild strain. By the concentration $\mathrm{EMS}_{3}$ a significant increase in total lipids content as it reached $25 \%$ compared with wild strain.

Table 2. The output of chemical mutation

\begin{tabular}{c|c}
\hline $\begin{array}{c}\text { Exposure } \\
\%\end{array}$ & Total Lipids \\
\hline Wild strain $(0.0)$ & 20.0 \\
EMS $_{1}(0.1)$ & 16.2 \\
$\mathrm{EMS}_{2}(0.01)$ & 20.3 \\
$\mathrm{EMS}_{3}(0.001)$ & 25.0 \\
\hline
\end{tabular}

That is result disaccord with the result (Kavakli $\boldsymbol{e t}$ al., 2017) the percentage of total lipids was increased in Chlorella vulgaris after EMS treatment with the ratio of $50 \%$.

\section{References}

Abbott I.A. and Cheney D.P. (1982). Commercial uses of algal products: introduction and bibliography. In: Rosowski JR, Parker BC, editors. Selected Papers in Phycology II. Lawrence, KS, USA: Phycological Society of America, pp. 779-787.

A.O.A.C. (1984). official methods of analytical chemists. $14^{\text {th }}$ ed. Washington, DC.

Bigogno C.; Khozin-Goldberg I.; Boussiba, S., Vonshak A. and Cohen, Z. (2002). Lipid and fatty acid composition of the green oleaginous alga Parietochlorisincisa, the richest plant source of arachidonic acid. Phytochemistry, 60, 497503.

Bongsoo L.; Gang-Guk C.; Yoon-E. C.; Minji S.; Min S. P. and Ji-Won Y. (2014). Enhancement of lipid productivity by ethyl methane sulfonatemediated random mutagenesis and proteomic analysis in Chlamydomonas reinhardtii. Korean J. Chem. Eng., 31(6), 1036-1042.
Doyle J. J. and Doyle, J. L. (1987). A rapid DNA isolation procedure for small quantities of fresh leaf tissue. Phytochem Bull 1987; 19: 11-15.

Ehsan S.; Mehmet T.; Yigit S.U.; Salim S.; Gul C.; Can E. and Ibrahim H. (2017). Understanding lipid metabolism in high-lipidproducing Chlorella vulgaris mutants at the genome-wide level. Algal Research, 28: 244252.

Fawley M.W.; Fawley K.P. and Buchheim M.A. (2004). Molecular diversity among communities of freshwater microchlorophytes. Microbial Ecol, 48: 489-499.

Fogg G.E. (1971). Recycling through algae. P. Roy. Soc. Lond Bio. 179: 201-207.

Gary A. S. (1984). A review of the genetic effects of ethyl methane sulfonate. Mutation Research, 134: 113-142.

Golueke C.G. and Oswald W.J. (1964). Role of plants in closed systems. Annul Rev. Plant Phys., 15: 387-408.

Hanagata N. (1998). Phylogeny of the sub family Scotiellocystoideae (Chlorophyceae, Chlorophyta) and related taxa inferred from $18 \mathrm{~S}$ ribosomal RNA gene sequence data. J. Phycol. 34: 10491054.

Huss, V. A. R.; Frank, C.; Hartmann, E. C.; Hirmer M.; Kloboucek A.; Seidel B. M.; Wenzeler P. and Kessler E. (1999). Biochemical taxonomy and molecular phylogeny of the genus Chlorella sensulato(Chlorophyta). J. Phycol., 35, 587-598.

John D.M.; Whitton B.A. and Brook A.J. (2003). The Freshwater Algal Flora of the British Isles: An Identification Guide to Freshwater and Terrestrial Algae. The Natural History Museum and the British Phycological Society. Cambridge, UK: Cambridge University Press.

Levasseur M.; Thompson P.A. and Harrison P.J. (1993). Physiological acclimation of marine phytoplankton to different nitrogen sources. J. Phycol., 29:587-595.

Loveless A. (1958). Increased rate of plaque-type and host-range mutation following treatment of bacteriophage in vitro with ethyl methane sulphonate, Nature, 181: 1212-1213.

Luo, W.; Pröschold, T.; Bock C. and Krienitz L. (2010). Generic concept in Chlorella - related coccoid green algae (Chlorophyta, Trebouxiophyceae). Plant Biology 12: 545- 553.

Mansour M.P.; Volkman J.K. and Blackburn S.I. (2003). The effect of growth phase on the lipid class, fatty acid and sterol composition in the marine dinoflagellate, Gymnodinium sp. in batch culture. Phytochemistry, 63, 145-153.

Saitou N. and Nei M. (1987). The Neighborjoining Method: A New Method for Reconstructing Phylogenetic Trees. Mol. Biol. Evol., 4(4): 406425.

Stanier R. Y.; Kunisawa, R.; Mandel, M. and Cohen-Bazire G. (1971). Purification and 
properties of unicellular blue-green algae (order Chroococcales). Bacteriol. Rev., 35: 171-205.

Stein, J.R. (1973). Hand book of phycological methods. Cambridge Univ. Press. Cambridge., UK.
Uclés, R. M. (2008). Identification of algal strains by PCR amplification and evaluation of their fatty acid profiles for biodiesel production, Master of Science, Louisiana State University.

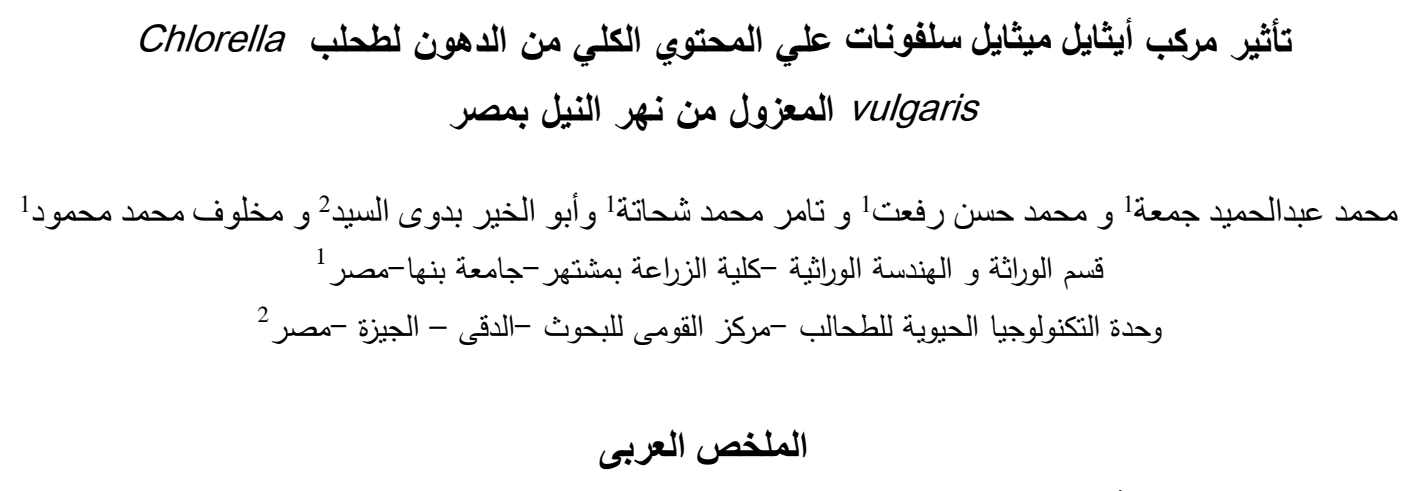

تم عزل الطحلب الأخضر Chlorella vulgaris من نهر النيل ,محافظة القليوبية , مصر ـ تم قياس معدل النمو

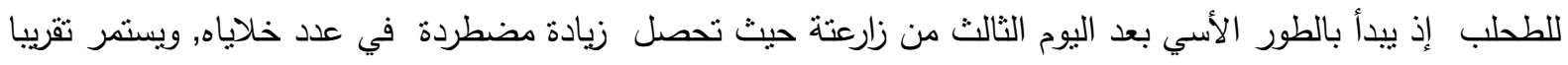

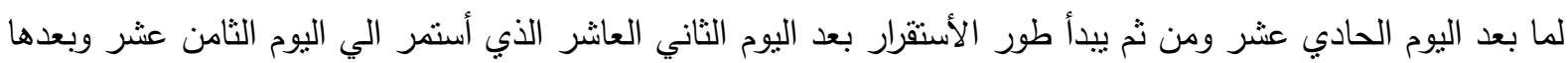

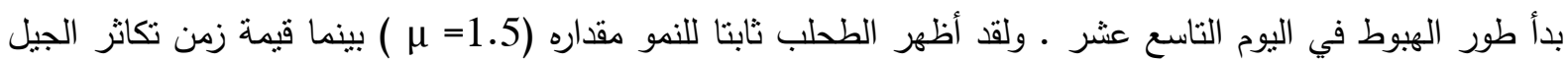

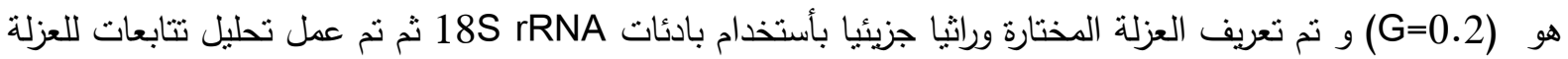
وقورنت تلك السلالة مع 10 سلالات مرجعية متاحة من بنك الجينات بواسطة أدوات المعلومانية الحيوية. وقد قدرت أنتاجية الطحلب من الدهون وكانت 20.0\%.في محاولة لزيادة محتوي الطحلب من الدهون الكلية تم أستحداث طفور كيماوي بواسطة رركب EMS و تم أستخدام ثلاث تركيزات (0.1 , 0.01 و 0.001) لمدة ساعتين. في حالة التركيز 0.1 أنخفضت

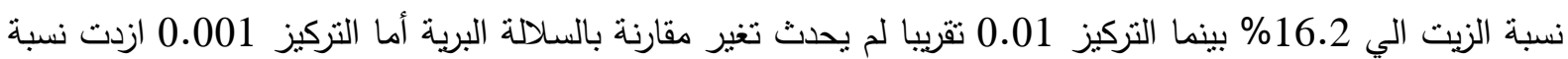
الزيت زيادة معنوية الي 25.0\% مقارنة بالسلالة البرية. 